\title{
Does stem length matter?
}

\author{
Stem uzunluğu önemli mi?
}

O. Şahap Atik, MD.

Department of Orthopedics and Traumatology, Medical Faculty of Gazi University, Ankara, Turkey

There are still some controversial issues regarding total hip arthroplasty including cemented vs. cementless, short stem vs. long stem. A literature review on the currently published survival results of short stems is encouraging and appears to be comparable with that of traditional uncemented stems. However, only few midterm and long-term follow-up studies are available; studies with more patients and longer follow-up periods are needed.

Keywords: Hip arthroplasty; stem length.

Long stems increase stress in the stem and distal stress transfer with shielding of proximal bone whereas short stems increase stress proximally, which may exceed the strength of cement or bone..$^{[1]}$

Metaphyseal-fitting short stems provide theoretical advantages compared with conventional stems decreasing proximal stress shielding, the risk of aseptic loosening and perioperative fractures. ${ }^{[2]}$

In late eighties, a short-stemmed femoral implant differing from conventional design was used in total hip arthroplasty in Mayo Clinic. ${ }^{[3]}$ Results of 20 patients with at least one year of follow-up study was encouraging.

Bone mineral density changes around short, metaphyseal-fitting, and conventional cementless anatomical femoral components were compared in another study. ${ }^{[4]}$ Bone mineral density was significantly increased in femoral zone 1 but slightly decreased in zone 7 in the short, metaphyseal-fitting stem group. In the conventional metaphyseal- and diaphyseal-fitting stem group, bone mineral density
Total kalça artroplastisine ilişkin hala tartışılan konular vardır: çimentolu ya da çimentosuz, kısa veya uzun stem gibi. Kısa stemlerin ömürlerine ilişkin literatür taraması sürenin geleneksel çimentosuz stemlere benzer olması nedeniyle cesaret vericidir. Ancak, orta ve uzun süreli çalışmalar az sayıdadır; daha çok hasta içeren ve daha uzun süreli çalışmalar gereklidir.

Anahtar sözcükler: Kalça artroplastisi; stem uzunluğu.

was markedly decreased in both zones 1 and 7. The mean follow-up was 3.35 years in both groups.

In other series with mean follow-up of 4.5-5 years; short, metaphyseal fitting cementless femoral component achieved stable fixation without diaphyseal fixation, and there was minimal bone resorption due to stress-shielding in the calcar region. ${ }^{[5,6]}$

Seven-year data from the Australian Orthopaedic Association National Joint Replacement Registry revealed that there was no significant difference in the cumulative percent revision rate in the short stems $(3.4 \%$, 95\% CI 2.4-4.8\%) compared with the standard length stems $(3.5 \%, 95 \%$ CI 3.3-3.8\%) despite its use in a greater proportion of potentially more difficult developmental dysplasia of the hip cases. ${ }^{[7]}$

Patel et al. ${ }^{[8]}$ reported that short-stem implants provide solid, dependable fixation in osteoporotic bone at minimum two-year follow-up.

Survival of the short, metaphyseal-fitting cementless anatomic stem at seven years was similar

- Received: September 18, 2014 Accepted: October 23, 2014

- Correspondence: O. Şahap Atik, M.D. Gazi Üniversitesi Tıp Fakültesi Ortopedi ve Travmatoloji Anabilim Dalı, 06500 Beșevler, Ankara, Turkey. Tel: +90 312 - 2025528 Fax: +90 312 - 2129008 e-mail: satikmd@gmail.com 


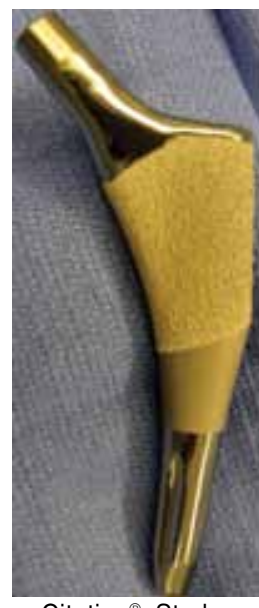

Citation ${ }^{\circledR}$; Stryker

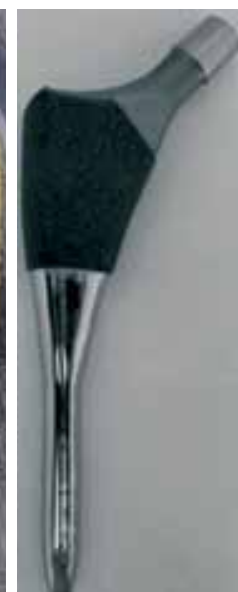

IPS $^{\mathrm{TM}}$, DePuy

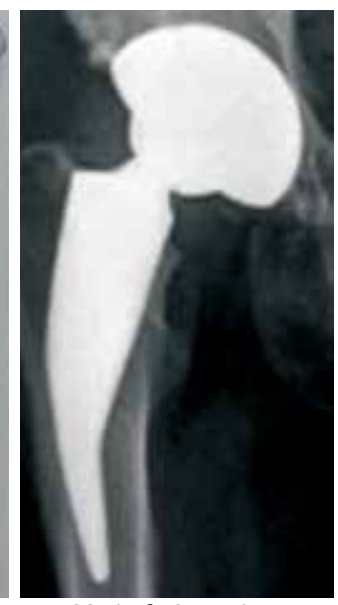

Metha ${ }^{\circledR}$, Aesculap
Figure 1. Several designs of short stems of different brands.

for A, B, C classes of bones (healthy and osteporotic bones) $\left(100 \%, 100 \%\right.$, and $98.2 \%$, respectively). ${ }^{[9]}$

The limited periprosthetic bone remodelling observed after a minimum of nine years follow-up suggests that this type of implant may improve mechanical stresses on host bone compared with standard stems requiring diaphyseal fixation. ${ }^{[10]}$

There are still some controversial issues regarding total hip arthroplasty including cemented vs. cementless, short stem vs. long stem. ${ }^{[1]]}$ A systematic literature review was performed to provide an overview on the currently published survival results of short stems to allow comparison with the results of traditional hip stems. ${ }^{[12]}$ The survival rate of these stems is encouraging and appears to be comparable with that of more traditional uncemented stems. However, only few mid-term and long-term follow-up studies are available; studies with more patients and longer follow-up periods are needed.

\section{Declaration of conflicting interests}

The author declared no conflicts of interest with respect to the authorship and/or publication of this article.

\section{Funding}

The author received no financial support for the research and/or authorship of this article.

\section{REFERENCES}

1. Berry JD, Duffy GP. Cemented femoral components. In: Morrey BF, editor. Joint replacement arthroplasty. Philadelphia: Churchill-Livingstone; 1996. p. 620.

2. Floerkemeier T, Gronewold J, Berner S, Olender G, Hurschler $\mathrm{C}$, Windhagen $\mathrm{H}$, et al. The influence of resection height on proximal femoral strain patterns after Metha short stem hip arthroplasty: an experimental study on composite femora. Int Orthop 2013;37:369-77.

3. Morrey BF. Short-stemmed uncemented femoral component for primary hip arthroplasty. Clin Orthop Relat Res 1989;249:169-75.

4. Kim YH, Choi Y, Kim JS. Comparision of bone mineral density changes around short, metaphyseal-fitting, and conventional cementless anatomical femoral components. J Arthroplasty 2011;26:931-40.

5. Kim YH, Kim JS, Joo JH, Park JW. A Prospective short-term outcome study of a short metaphyseal fitting total hip arthroplasty. J Arthroplasty 2012;27:88-94.

6. Patel RM, Lo WM, Cayo MA, Dolan MM, Stulberg SD. Stable, dependable fixation of short-stem femoral implants at 5 years. Orthopedics 2013;36:e301-7.

7. GGH Choy, JA Roe, SL Whitehouse, KS Cashman, RW Crawford. Exeter short stems compared with standard length Exeter stems: Experience from the Australian Orthopaedic Association National Joint Replacement Registry. J Arthroplasty 2013;28:103-9.

8. Patel RM, Smith MC, Woodward CC, Stulberg SD. Stable fixation of short-stem femoral implants in patients 70 years and older. Clin Orthop Relat Res 2012;470:442-9.

9. Kim YH, Park JW, Kim JS. Primary total hip arthroplasty in patients with osteoporotic bone (Class C Bone)? J Arthroplasty 2013;28:139-46.

10. Cinotti G, Della Rocca A, Sessa P, Ripani FR, Giannicola G. Thigh pain, subsidence and survival using a short cementless femoral stem with pure metaphyseal fixation at minimum 9-year follow-up. Orthop Traumatol Surg Res 2013;99:30-6.

11. Atik OS. Hybrid or reverse hybrid for total hip arthroplasty? Eklem Hastalık Cerrahisi 2013;24:1.

12. Rometsch E, Bos PK, Koes BW. Survival of short hip stems with a "modern", trochanter-sparing design - a systematic literature review. Hip Int 2012;22:344-54. 